\title{
Pengaruh $\mathrm{CdCl}_{2}$ terhadap Produksi Eksopolisakarida dan Daya Hidup Azotobacter
}

\author{
Reginawanti Hindersah ${ }^{1 *}$, Dedeh Hudaya Arief'1), Soetijoso Soemitro²), \\ dan Lukman Gunarto3) \\ 1)Fakultas Pertanian, Universitas Padjadajran, Bandung \\ 2) Jurusan Kimia, FMIPA, Universitas Padjadjaran, Bandung \\ ${ }^{3)}$ Balai Besar Penelitian Bioteknologi dan Sumber Daya Genetika, Bogor \\ Diterima 07-11-2008 Disetujui 07-03-2009
}

\begin{abstract}
The contamination of toxic heavy metal Cadmium $(\mathrm{Cd})$ in soils will be endanger the human health because it is more available comparing to another toxic heavy metals. One method of Cd-contaminated soil bioremediation is using exopolysachharide-producing bacteria Azotobacter. Exopolysachharides (EPS) can mobilize Cd through the formation of complex Cd-EPS which sequentially can increase the availability of Cd for plants uptake. A laboratory experiment has been done to study the EPS production and the viability of six Azotobacter isolates in the liquid culture containing $0.01,0.1$, and $1 \mathrm{mM} \mathrm{CdCl}_{2}$. The bacteria were cultured in liquid medium with and without $\mathrm{CdCl}_{2}$ for 72 hours at room temperature. The EPS production was determined by gravimetric method after precipitation using acetone and centrifugation at $7000 \mathrm{rpm}$. The result was that all of Azotobacter isolates produce EPS in the presence of $\mathrm{CdCl}_{2}$. In the culture with $1 \mathrm{mM} \mathrm{CdCl}$, the density of Azotobactersp. isolate BS3, LK5, LKM6 increased significantly, and that of isolate LH16 decreased. No significant effect of $\mathrm{CdCl}_{2}$ on the density of isolate BS2 and LH15. This research suggested that some Azotobacter isolates were relatively resistence to the $\mathrm{Cd}$ and could be developed as biological agents in Cd-contaminated soil bioremediation.
\end{abstract}

Keywords: Cadmium, Azotobacter, Exopolysachharides, Bioremediation

\section{PENDAHULUAN}

Kadmium (Cd) adalah logam berat toksik yang telah ada di dalam tanah sebagai akibat dari proses pedogenesis (Alloway, 1995). Kontaminan Cd di tanah dapat berasal dari penambangan serta peleburan $\mathrm{Zn}$ dan S, limbah industri, aplikasi sludge, serta pupuk fosfat (Alloway, 1995, Chien et al., 2003). Kadmium adalah logam berat yang paling mendapatkan perhatian karena lebih mudah diadsorpsi daripada logam $\mathrm{Zn}, \mathrm{Ni}$, $\mathrm{Cu}$, dan Pb (Vries \& Tiller, 1978; Alloway, 1995). Dengan demikian $\mathrm{Cd}$ mudah diserap tanaman dan memasuki rantai makanan. Bahaya peningkatan $\mathrm{Cd}$ di tanah adalah peningkatan Cd di tanaman konsumsi yang tidak dapat teramati karena tanaman sering tidak memperlihatkan gejala keracunan meskipun mengakumulasi Cd dalam jumlah berlebih (Peijnenburg et al., 2000). Hal ini disebabkan karena tanaman dapat menghindari keracunan logam berat terutama $\mathrm{Cd}$ melalui sintesis peptida fiteokelatin (Cobbett, 2000; Ishmayana et al., 2007) yang mengikat Cd dan

\footnotetext{
*Telp: +62811221834

Email: reginawanti@yahoo.com
}

membawanya ke vakuola (Cobbett, 2000), sehingga tidak memasuki sistem metabolisme tanaman.

Bioremediasi adalah teknologi yang dikembangkan untuk restorasi tanah tercemar logam berat karena relatif mudah, murah dan berkelanjutan (Lasat et al., 2002). Bakteri yang menghasilkan eksopllisakarida (EPS) berpotensi untuk digunakan sebagai agen bioremediasi. Eksopolisakarida adalah suatu struktur ekstrasel yang dapat mengkelat logam dan meningkatkan ketersediaan hayati $\mathrm{Cd}$ di tanah (Chen et al., 1995). Kompleks EPS-Cd bersifat seperti siderofor yang memudahkan serapan Cd oleh tanaman. Dengan demikian bioremediasi logam berat oleh bakteri dapat dilakukan bersamaan dengan ekstraksi logam oleh tanaman hiperakumulator (Brooks, 1998) sehingga proses restorasi tanah tercemar logam berat $\mathrm{Cd}$ mejadi lebih efektif.

Bakteri tanah Azotobacter, yang sudah digunakan sebagai pupuk hayati, menghasilkan EPS dalam jumlah signifikan (Vermani, 1997; Emtiazi et al., 2004; Hindersah et al., 2006) dan dapat meningkatan serapan Cd tanaman (Hindersah et al., 2004; Hindersah \& Kalay, 
2006). Selain itu, bakteri ini juga dapat diisolasi dari sludge Instalasi Pengolahan Air Limbah yang mengandung $4.73 \mathrm{mg} \mathrm{kg}^{-1} \mathrm{Cd}$ (Hindersah et al., 2004). Namun efek Cd terhadap produksi EPS Azotobacter belum banyak dilaporkan. Penelitian ini bertujuan untuk mempelajari produksi EPS dan daya hidup beberapa isolat Azotobacter di dalam kultur cair yang mengandung $0.01,0.1$, dan $1 \mathrm{mM} \mathrm{CdCl}$.

\section{BAHAN DAN METODE}

Isolat Azotobacter. Azotobacteryang diuji pada penelitian laboratorium ini adalah enam isolat Azotobacter sp. koleksi Laboratorium Biologi dan Bioteknologi Tanah Fakultas Pertanian Universitas Padjadjaran. Isolat BS2 dan BS3 diisolasi dari sludge IPAL PDAM (3.74 $\mathrm{mg} \mathrm{kg}^{-1} \mathrm{Cd}$ ), LKM5 dan LKM6 diisolasi dari rizosfer kubis merah $\left(481 \mathrm{\mu g} \mathrm{kg}^{-1} \mathrm{Cd}\right)$, dan LH15 dan LH16 diisolasi dari Andisols di hutan Lembang $\left(117 \mu \mathrm{g} \mathrm{kg}^{-1} \mathrm{Cd}\right)$. Seluruh isolat dipelihara di agar miring dengan media menurut (Vermani et al. 1997).

Metode Inkubasi. Enam isolat Azotobacter ditumbuhkan di dalam media cair Vermani tanpa dan dengan $0.01 \mathrm{mM}, 0.1 \mathrm{mM}$ dan $1 \mathrm{mM} \mathrm{CdCl}$. Sepuluh persen biakan murni dengan konsentrasi $10^{9} \mathrm{cfu} \mathrm{mL}^{-1}$ ditambahkan ke dalam $20 \mathrm{~mL}$ media cair Vermani di dalam tabung reaksi $100 \mathrm{~mL}$. Inkubasi dilakukan di atas pengocok dengan $115 \mathrm{rpm}$ pada suhu kamar selama 72 jam. Setelah inkubasi, konsentrasi EPS dan sel bakteri di dalam kultur diamati.

Penentuan produksi EPS. Produksi EPS oleh Azotobacter di dalam kultur cair ditentukan dengan metode ekstraksi aseton dan sentrifugasi (Vermani et al., 1997) yang dimodifikasi (Hindersah et al., 2006). Sebanyak $10 \mathrm{~mL}$ kultur disentrifugasi $7000 \mathrm{rpm}$ selama 20 menit di suhu kamar. Sebanyak $20 \mathrm{~mL}$ aseton dingin ditambahkan ke dalam supernatan dan disentrifugasi kembali. EPS di dasar tabung dikoleksi dan ditimbang di atas kertas saring setelah dipanaskan $35^{\circ} \mathrm{C}$ selama 1 jam. Konsentrasi sel bakteri di dalam kultur cair ditentukan dengan metode Pengenceran Plat menurut Schinner et al., (1995) pada media agar Vermani dengan modifikasi. Sebanyak sepuluh $\mu \mathrm{L}$ suspensi pada pengenceran $10^{-5}, 10^{-6}$ dan atau $10^{-7}$ (tergantung dari konsentrasi $\mathrm{CdCl}_{2}$ di dalam kultur) diteteskan di permukaan media agar Vermani. Media diinkubasi pada suhu $30^{\circ} \mathrm{C}$ selama 18 jam. Koloni yang tumbuh dihitung di bawah mikroskop stereo Olympus $\mathrm{BH} 3$ pada perbesaran 100 kali.

Percobaan ini dirancang dalam rancangan acak lengkap pola faktorial dengan tiga ulangan. Data dianalisis dengan analisis ragam dan dilanjutkan dengan Uji Jarak Berganda Duncan pada taraf 0.05 menggunakan SigmaStat 2.01 (Analitical software by JEZI Installer Version 3.0. Germany).

\section{HASIL DAN PEMBAHASAN}

Hasil percobaan ini menunjukkan bahwa produksi EPS setiap isolat tidak ditentukan oleh konsentrasi kadmium klorida $\left(\mathrm{CdCl}_{2}\right)$ di dalam media (Tabel 1). Kemampuan setiap isolat dalam menghasilkan EPS tidak sama. Produksi EPS isolat LKM6 lebih besar 4 .2-31.7\% daripada isolat lainnya, sedangkan produksi EPS isolat BS3 sama besar dengan isolat $\mathrm{AH} 15$ tetapi lebih besar daripada isolat lain selain isolat LKM6. Produksi EPS tidak berubah jika ke dalam media ditambahkan $\mathrm{CdCl}_{2}$ sebanyak 0,01 mM (Tabel 1), sedangkan produksi EPS pada media yang mengandung $0,1 \mathrm{mM} \mathrm{CdCl}{ }_{2}$ meningkat dengan nyata dibandingkan kontrol. Namun peningkatan konsentrasi $\mathrm{CdCl}_{2}$ di dalam media cair sampai $1 \mathrm{mM}$ menekan produksi EPS.

Pada bakteri Azotobacter pemfiksasi nitrogen, polisakarida ekstraseluler dibentuk untuk menahan kekeringan, stres lingkungan, dan terutama melindungi nitrogenase dari oksigen (Sabra et al., 2000). Paparan Cd dalam konsentrasi kecil mungkin tidak menyebabkan efek toksik karena bakteri termasuk mikroba yang relatif toleran terhadap logam berat (Trevor et al., 1986). Peningkatan produksi EPS pada konsentrasi $\mathrm{CdCl}_{2}$ relatif rendah dapat diartikan sebagai mekanisme adaptasi terhadap logam berat (Chen et

Tabel 1. Produksi EPS oleh berbagai isolat Azotobacter di dalam kultur cair dengan berbagai konsentrasi $\mathrm{CdCl}_{2}$.

\begin{tabular}{|c|c|c|c|c|c|}
\hline & & $\mathrm{CdCl}_{2}$ & $\mathrm{nM})$ & & Doto roto \\
\hline Azotobacter & 0 & 0.01 & 0.1 & 1 & \\
\hline BS2 & 1.35 & 1.60 & 1.55 & 1.17 & $1.42 a b$ \\
\hline BS3 & 1.66 & 1.73 & 1.87 & 1.12 & $1.60 \mathrm{~b}$ \\
\hline LK5 & 1.40 & 1.40 & 1.57 & 0.65 & $1.25 \mathrm{a}$ \\
\hline LKM6 & 1.83 & 1.77 & 1.98 & 1.07 & $1.67 \mathrm{c}$ \\
\hline LH15 & 1.78 & 1.68 & 1.90 & 1.17 & $1.63 \mathrm{~b}$ \\
\hline LH16 & 1.18 & 1.17 & 1.43 & 0.78 & $1.14 \mathrm{a}$ \\
\hline Rata-rata & $1.53 b^{*}$ & $1.56 \mathrm{bc}$ & $1.72 \mathrm{c}$ & $0.99 a$ & \\
\hline
\end{tabular}

*Angka rata-rata yang diikuti huruf yang sama berbeda tidak nyata menurut uji Jarak Berganda Duncan 5\% 
al., 1995b). Peningkatan produksi EPS diperlukan untuk adsorpsi $\mathrm{Cd}^{2+}$ agar tidak memasuki proses fisiologis bakteri. Emtiazi et al., (2004) membuktikan bahwa EPS Azotobacter sp. strain AC2 dapat mengadsorpsi logam berat $\mathrm{Zn}^{2+}$ yang memiliki struktur kimia mirip dengan $\mathrm{Cd}^{2+}$.

Berbeda dengan produksi EPS, konsentrasi sel isolat Azotobacter ditentukan konsentrasi $\mathrm{CdCl}_{2}$ (Tabel 2). Pada awal inkubasi, konsentrasi sel Azotobacter di dalam kultur cair Vermani untuk setiap isolat adalah sekitar $10^{8} \mathrm{cfu} \mathrm{mL}^{-1}$ sedangkan di akhir inkubasi menjadi sekitar $10^{10} \mathrm{cfu} \mathrm{mL}^{-1}$ (Tabel 2)

Kemampuan setiap isolat untuk tumbuh di beberapa konsentrasi $\mathrm{CdCl}_{2}$ tidak sama. Pertumbuhan isolat BS2 dan LH15 tidak berubah di setiap konsentrasi $\mathrm{CdCl}_{2}$, sedangkan pertumbuhan isolat $\mathrm{LH} 16$ menurun pada 0.1 dan $1 \mathrm{mM} \mathrm{CdCl}_{2}$. Konsentrasi sel isolat $\mathrm{BS} 3$, LK5, LKM6 meningkat pada 0.1 dan $1 \mathrm{mM} \mathrm{CdCl}$, yang menjelaskan daya adaptasi terhadap perubahan konsentrasi $\mathrm{CdCl}_{2}$ di dalam media (Tabel 2). Jika konsentrasi sel di awal inkubasi menjadi pertimbangan, maka peningkatan konsentrasi sel isolat LKM6 lebih besar daripada isolat LK5. Peningkatan tersebut adalah $4.5 \times 10^{2}$ untuk isolat LKM6 dan $3.7 \times 10^{2}$ untuk isolat LK5. Secara umum, pertumbuhan keenam isolat Azotobacter di bawah pengaruh $\mathrm{CdCl}_{2}$ tidak berubah sampai satu unit log yang menggambarkan resistensi Azotobacter terhadap Cd.

Kadmium adalah polutan yang berpotensi meracuni tanah. Bakteri memiliki mekanisme tertentu untuk mengurangi keracunan logam. Sejumlah bakteri memiliki plasmid yang mengkode resistensi sehingga penyerapan Cd dapat dikurangi (Trevors et al., 1986). Resistensi bakteri Gram negatif untuk menurunkan akumulasi logam berat di sel melalui pompa efluks telah dijelaskan oleh Nies (1992). Sistem ini didorong oleh protein resistensi, P-type ATPases, fasilitator difusi kation dan protein porter, serta faktor resistensi NreBand CnrT (Stuczynski et al., 2003). Pada bakteri Gram negatif Alcaligens eutrophus, efluks ion $\mathrm{Co}^{2+}, \mathrm{Zn}^{2+}$, dan $\mathrm{Cd}^{2+}$ memerlukan protein $\mathrm{Czc} A, \mathrm{CzcB}$, dan $\mathrm{CzcC}$ dan diregulasi oleh CzcD (Nies et al., 1992)

Penelitian (Boularbah et al., 1992) membuktikan bahwa akumulasi Cd di bakteri yang resisten akan meningkat sejalan dengan peningkatan konsentrasi $\mathrm{Cd}$ sampai $100 \mathrm{mg} \mathrm{mL}^{-1}$ di larutan. Dijelaskan pula bahwa Bacillus brevis lebih resisten daripada $B$. Subtilis, dan dapat mengakumulasi $\mathrm{Cd}$ sampai $70 \mathrm{mg} \mathrm{g}^{-1}$ bobot kering sel.

Belum ada penjelasan mengenai resistensi bakteri Gram negatif Azotobacter terhadap Cd melalui mekanisme seperti yang dijelaskan di atas. Efek toksik Cd terhadap Azotobacter lebih dikaitkan dengan aktivitas fiksasi nitrogen. Aktivitas nitrogenase bakteri ini mulai menurun pada 0.5 dan $1 \mathrm{mg} \mathrm{kg}^{-1} \mathrm{Cd}$ dan terhenti pada $5 \mathrm{mg} \mathrm{kg}^{-1} \mathrm{Cd}$ karena $\mathrm{Cd}$ menghambat glutamin sintase (GS) dan glutamat sintase (GOGAT) melalui pengikatan $\mathrm{Cd}$ oleh gugus tiol (Kothandarman et al., 2002). Sehubungan dengan EPS yang diproduksi Azotobacter pada percobaan ini, resistensi Azotobacter isolat BS3, LK5, LKM6, dan LH15 terhadap 0,01-1 $\mathrm{mM} \mathrm{CdCl}_{2}$ dapat disebabkan

Tabel 2. Konsentrasi sel (x $10^{10}$ sel mL $^{-1}$ ) berbagai isolat Azotobacter di dalam kultur cair dengan berbagai konsentrasi CdCl ${ }_{2}$

\begin{tabular}{|c|c|c|c|c|}
\hline \multirow{2}{*}{ Isolat Azotobacter } & \multicolumn{4}{|c|}{$\mathrm{CdCl}_{2}(\mathrm{mM})$} \\
\hline & 0 & 0.01 & 0.1 & 1 \\
\hline BS2 & $2.3 \mathrm{a}$ & $1.83 \mathrm{a}$ & $1.87 \mathrm{a}$ & $1.75 \mathrm{a}$ \\
\hline$\left(1.17 \times 10^{8}\right.$ sel mL $\left.\mathrm{m}^{-1}\right)$ & $A$ & $A$ & $A$ & A \\
\hline BS3 & $2.9 \mathrm{a}$ & $3.18 b$ & $3.74 b$ & $4.54 \mathrm{~b}$ \\
\hline$\left(1.18 \times 10^{8} \mathrm{sel} \mathrm{mL} L^{-1}\right)$ & $A$ & $A$ & B & B \\
\hline LK5 & $2.49 \mathrm{a}$ & $2.88 \mathrm{~b}$ & $3.31 \mathrm{~b}$ & $4.26 \mathrm{~b}$ \\
\hline$\left(1.14 \times 10^{8} \mathrm{sel} \mathrm{mL} L^{-1}\right)$ & $A$ & $A$ & B & B \\
\hline LKM6 & $2.51 \mathrm{a}$ & $3.2 \mathrm{~b}$ & $4.01 \mathrm{~b}$ & $4.68 \mathrm{~b}$ \\
\hline$\left(1.04 \times 10^{8} \mathrm{sel} \mathrm{mL} L^{-1}\right)$ & A & A & $\mathrm{B}$ & B \\
\hline LH15 & $9.06 \mathrm{~b}$ & $8.97 \mathrm{c}$ & $8.77 \mathrm{c}$ & $9.48 \mathrm{c}$ \\
\hline$\left(2.01 \times 10^{8}\right.$ sel mL $\left.\mathrm{m}^{-1}\right)$ & $A$ & A & $A$ & A \\
\hline LH16 & $7.24 \mathrm{~b}$ & $8.12 \mathrm{c}$ & $3.91 \mathrm{~b}$ & $4.11 \mathrm{~b}$ \\
\hline$\left(1.55 \times 10^{8} \mathrm{sel} \mathrm{mL} L^{-1}\right)$ & B & $B$ & $A$ & $A$ \\
\hline
\end{tabular}

Angka di dalam kurung adalah konsentrasi sel setiap isolat sebelum inkubasi

"Angka yang diikuti huruf yang sama tidak nyata menurut uji Jarak Berganda Duncan $5 \%$. Huruf kecil dibaca arah vertikal dan huruf besar dibaca arah horisontal. 
pembentukan EPS yang diinduksi Cd. Selanjutnya EPS menghilangkan efek toksik Cd dengan cara mengikat ion logam melalui ikatan ionik dan koordinasi (Chen et al., 1995). Eksopolisakarida terikat lemah di dinding sel Azotobacter (Cohen \& Johnstone, 1964) sehingga EPS yang mengikat $C d$ dapat terlepas dari sel dan $\mathrm{Cd}$ tidak memasuki sistem metabolisme sel Azotobacter.

\section{KESIMPULAN}

Setiap isolat Azotobacter dapat memproduksi EPS dengan keberadaan $\mathrm{CdCl}_{2}$. Namun, dengan mengabaikan isolat, $\mathrm{CdCl}_{2}$ menurunkan produksi EPS. Produksi EPS di media tanpa $\mathrm{CdCl}_{2}$ adalah $1.53 \mathrm{mg}$ $\mathrm{kg}^{-1}$, dan menurun sampai $0.99 \mathrm{mg} \mathrm{kg}^{-1}$ di media dengan $1 \mathrm{mM} \mathrm{CdCl}_{2}$. Di lain pihak, peningkatan $\mathrm{CdCl}_{2}$ sampai $1 \mathrm{mM}$ meningkatkan populasi Azotobacter sp. isolat BS3, LK5, LKM6, menurunkan populasi Azotobacter sp. Isolat dan LH16, tetapi tidak berpengaruh terhadap populasi sel isolat BS2 dan LH15. Penelitian ini membuktikan bahwa Azotobacter relatif resisten terhadap Cd dan dapat memproduksi EPS dengan keberadaan $\mathrm{Cd}$.

\section{UCAPAN TERIMAKASIH}

Penelitian ini didanai oleh Dana Hibah Bersaing Dirjen DIKTI dengan nomor kontrak 013/SP2H/PP/ DP2M/III/2007. Kami berterimakasih kepada Kepala Balai Pengawasan dan Sertifikasi Benih Tanaman Pangan dan Hortikultura Dinas Pertanian Jawa Barat atas izin penggunaan peralatan di laboratorium Hortikultura dan Aneka Tanaman.

\section{DAFTAR PUSTAKA}

Alloway, B.J. 1995. Cadmium. Di dalam: Alloway, B.J (ed). Heavy Metals in Soils. Glasgow: Blackie Academic \& Professional.

Boularbah, A., Morel, J.L., Bitton, G., \& Guckert, A. 1992. Cadmium biosorption and toxicity to six cadmium-resistantgram positive bacteria isolated from contaminated soil. Environ. Toxic. and water qual. 7: 237-246.

Brooks, R.R. 2000. Phytochemistry of Hyperaccumulators Di dalam: Brooks, R.R. (ed). Plants that Hyperaccumulate Heavy Metals. Cambridge: CAB International.

Chen, J.H., Lion, L.W., Ghiorse, W.C., \&. Shuler, M.L. 1995a. Mobilization of adsorbed cadmium and lead in aquifer material by bacterial extracellular polymers. Water Res. 29: 421-430.

Chen, J.H., Czajka, D.R., Lion, L.W., Shuler, M. L. \& Ghiorse, W.C. 1995b. Trace metal mobilization in soil by bacterial polymers. Environ. Health Perspect. 103: 53-58.
Chien, S.H., Carmona, G., Prochnow, L.L., \& Austin, E.R. 2003. Cadmium avalability from granulated and bulk-blended phosphate-potassium fertilizers. J. Environ. Qual. 32: 19111914.

Cobbett, C.S. 2000. Phytochelatins and their roles in heavy metal detoxification. Plant Physiol. 123:825-832.

Cohen, G.H. \& Johnstone. D.B.1964. Capsular polysachharide of Azotobacter agilis. J. Bacteriol. 88: 1695-1699.

Emtiazi, G., Ethemadifar, Z., \& Habibi, M.H. 2004. Production of extracellular polymer in Azotobacter and biosorption of metal by exopolymer. Afr. J. Biotech. 3:330-333.

Hindersah, R., Muntalif, B.S. \& Kalay, A.M. 2004a. Isolasi dan identifikasi mikroorganisme aerob dari lumpur kolam Anaerob di Instalasi Pengolahan Air Limbah Bandung. Makalah disampaikan pada Pertemuan IImiah Tahunan Persatuan Mikrobiologi. Semarang, 27-29 Agustus 2004.

Hindersah, R., Arief, D.H., \& Kalay. A.M. 2004b. Rhizobacteria Azotobacter: Influence on $\mathrm{Pb}$ and $\mathrm{Cd}$ adsorption by roots of sweet corn. Makalah disampaikan pada International Biotechnology Conference. Sanur, 1-3 Desember 2004.

Hindersah, R. \& Kalay, A.M. 2006. Akumulasi timah hitam dan kadmium pada tajuk selada setelah aplikasi Azotobacter dan lumpur IPAL.J. Budidaya Pertanian 2: 1-5.

Hindersah, R., Arief, D.H., Soemitro, S., \& Gunarto, L. 2006. Exopolysaccharide Extraction from Rhizobacteria Azotobactersp. Proc. International Seminar IMTGT. Medan, 22-23 Juni 2006. Hal 50-55.

Ishmayana, S., Rosita, N., Kristina, Y., Kamara, D.S., Hindersah, R., \& Soemitro, S. 2007. Komposisi asam amino peptida ã-glutamilsistein yang diisolasi dari tajuk selada (Lactuca sativa L.) dengan dan tanpa inokulasi Azotobacter sp. LKM6. Makalah dipresentasikan di Seminar Nasional Biokimia. Depok, 9 januari 2007.

Kothandaraman, R., Vasundhara, G., Kurup, G.M., Jacob, V.B., \& Sethuraj, M.R. 2002. Nitrogen fixation by Azotobacter chroococcum under cadmiun stress. Indian J. of Microbiol. 42: $15-17$.

Lasat, M.M. 2002. Phytoextraction of toxic metals. A review of biological mechanisms. J. Environ. Qual. 31: 109-120.

Nies, D.H. 1992. Resistance to cadmium, cobalt, zinc, and nickel in microbes. Plasmid. 27: 17-28.

Sabra, W., Zeng, A.P., Lunsdorf, H., \& Deckwer, W.D. 2000. Effect of oxygen on formation and structure of Azotobacter vinelandiialginate and its role in protecting nitrogenase. Appl. Environ. Microbiol. 66: 4037-4044.

Schinner, F., Ohlinger, R., Kandeler, E., \& Margesin, R. 1995. Methods in Soil Biology. Berlin Heidelberg: Springer-Verlag.

Stuczynski, T.I., McCarty, G.W., \& Siebielec, G. 2003. Response of soil microbiological activities to cadmium, lead, and zinc salt amendments. J. Environ. Qual. 32: 1346-1355.

Trevor, J.T., Stratton, G.W., \& Gadd, G.M. 1986. Cadmium transport, resistance, and toxicity in bacteria, algae, and fungi. Can. J. Microbiol. 32: 447-464.

Vermani, M.V., Kelkar, S.M., \& Kamat, M.Y. 1997. Studies in polysaccharide production and growth of Azotobacter vinelandii MTCC 2459, a plant rhizosphere isolate. Lett. Appl. Microbiol. 24: 379-383.

Vries, M.P.C. \& Tiller, K.G. 1978. The effect of sludge from two Adelaide sewage treatment plants on the growth of and heavy metal concentration in lettuce. Australian J. of Agric. and Animal Husban.18: 143-147. 